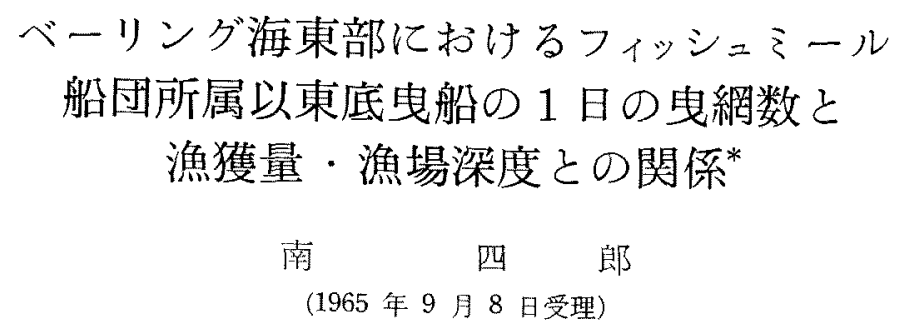

\title{
BATHYMETRIC CHANGE OF DAILY HAULS PER BOAT IN RELATION TO DAILY CATCH BY THE DANISH SEINERS OF A FISH-MEAL FLEET FISHING IN THE BERING SEA
}

\begin{abstract}
Shiro Minami**
This report dealt with the bathymetric change of the frequency distribution of daily hauls per boat in relation to the daily catch found in the daily reports of 22 Danish seiners of one of the fish-meal fleets fishing in the Bering Sea during an entire season in 1963. The tendency of increase in daily catch manifested, as stated in the previous reports ${ }^{12}{ }^{12}$, the necessity of discussion on the bathymetric difference in the daily hauls per boat being stratified according to the grades of daily catch. And the further stratification of the same records analyzed in the previous reports into the four grades of daily catch per boat of 10 ton intervals (the records were already stratified according to the fishing areas and the fishing depths of $10 \mathrm{~m}$ intervals) made it possible to get the following findings:

1. In most of the groups of samples, the frequency distribution of day-and-boats with respect of the number of daily hauls per boat plotted against $(11-x)$ on logarithmic scale was agreeable to the normal series (where a boat conducted $x$ hauls a day), although those of some of the groups were thought to be the modification of this type and those of the others with good catch were normalized. These facts suggested that the above-mentioned type may be indicative of daily hauls per boat of the Danish seiners probably with the uniform performance fishing in the same depth zones of the same areas.

2. The groups of samples yielded the same grades of daily catch per boat showed the tendency of decrease in daily hauls per boat with increase in fishing depth; this tendency was very conspicuous in Area A, whereas very faint in Area C. It became, therefore, clear that the same tendency found before the stratification of the records according to the grade of daily catch was not the false one owing to the bathymetric difference in daily catch but the probably essential one owing to that of some other factors of significance.

3. The groups of samples in the same depth zones showed the tendency of decrease in daily hauls per boat with increase in daily catch per boat, although the boats repeated to haul the net on the days yielded the catch of 10 to 19 tons a boat as frequently as or less frequently than on the days yieided the catch of 20 to 29 tons a boat.

4. The standard deviation of daily hauls per boat seemed to change dependently of either the fishing area or the fishing depth, but that of the samples in the same depth zone of the same area was similar to one another regardless of the grade of daily catch per boat.
\end{abstract}

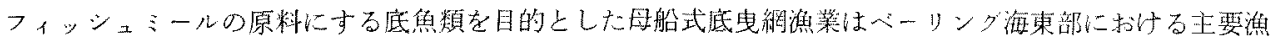

* 水辇大学校研究栄績 第 458 号

** 水諼大学校 (Shimonoseki College of Fisheries, Shimonoseki, Japan) 
業の一つである。その付属潐船には以東底曳船と以西底曳船があり, それらの比率は船団によりまた操業年 度に上り異なる。ここで报つた船団の付属漁船は前者が 22 隻, 後者が 6 隻のはか, 主に潐場調査に從事す るトロール船 1 隻により構成される。いずれの付属漁船も主として大陸棚上のコガネガレイ Limanda aspera（主要源場は深度 $50 \mathrm{~m}$ から $110 \mathrm{~m}$ まで）またはスケソウダラ Theragra chalcogrammus $(100 \mathrm{~m}$ から $150 \mathrm{~m}$ まで）漁獲している。潐獲物は母船にわたされフィッシュミールにされる。著者ら゙は 1963 年に出漁したする船団に所属する全以東底曳船 22 隻の漁獾日報を整理し次の結果を報告した：1）資料を 深度 $10 \mathrm{~m}$ ごとに層別化すると，各層において 1 日 1 隻が曳絧した回数 $x$ の頻度は $x=3$ から $7 \sim 9$ まで の間ゆるやかに增加しその後は急汇娍少する。2) そこで $x$ を $\log (11-x)$ に変換すると頻度分布は正規分布 に上〈適合する。3）各層に括いて 1 日に 1 隻が电網した回数の平均值は深度とともに減少する。

しかし1日1隻あたりの湿獲量は深度とともに增加するので，この深度の增加にともなつて电網回数が 減少する㑯向は，深度の增加が直接影響したためか潐獲量の增加などを通じて問接的に影響したためか孝確 める必要がある。そこでこの報告では，同じ深度層でほぼ同じ量の漁獲量をあげた場合の曳網回数頻度分布 をしらベ，その深度执よび漁獲量との関倸について諭ずる。

\section{資料の層 別 化}

この報告では前報 ${ }^{1 / 2)}$ と同じ資料 (1963 年に出漁したある船団に所属する 22 隻の以東底曳船の操策日報)

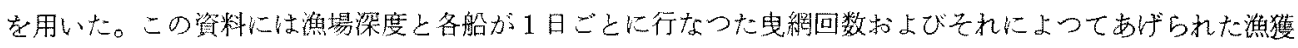
量が記されているので,この報告では各船 1 日ごとを単位として扱つた（すなわち海獾量むたは曳絧回数と は各船の1日ごとのそれらである。

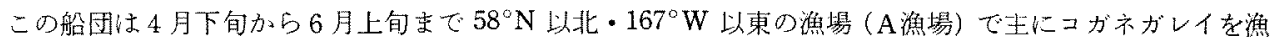
獲し，6月上旬か５8月上旬まで $58^{\circ} \mathrm{N}-60^{\circ} 30^{\prime} \mathrm{N} \cdot 171^{\circ} 30^{\prime} \mathrm{W}-175^{\circ} \mathrm{W}$ の潡場（B漁場）でスケンウダラを， その後 9 月下旬の終漁をで $59^{\circ} \mathrm{N}-62^{\circ} 30^{\prime} \mathrm{N} ・ 176^{\circ} 30^{\prime} \mathrm{W}-179^{\circ} \mathrm{W}$ の海場（C漁場）て同じくスケンウダラを海

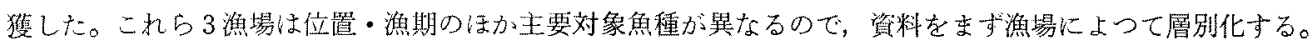

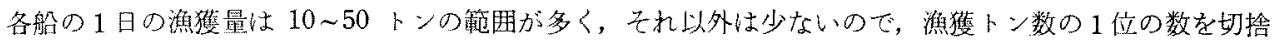
て 10 トンから 40 トン末での 4 階級に分け，乙れ以外はここでは报わない。

漁場の深度(この報文では精度を考兄 1 位の値を 4 唅 5 入して扱ら）は $50 \mathrm{~m}$ から $150 \mathrm{~m}$ までの広範囲 にわたるが，各㴔場に分けて考文ると，A漁場ては $50 \mathrm{~m}$ から $110 \mathrm{~m}, \mathrm{~B}$ 㴔場では主に $100 \mathrm{~m} \mathrm{から} 120 \mathrm{~m}$,

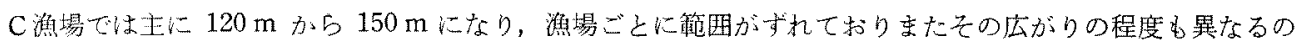

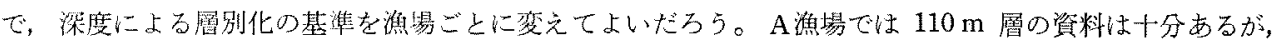

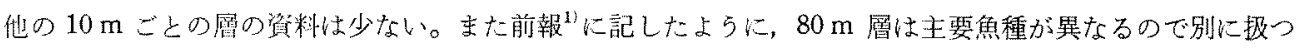
た力が上いが，漁獲量に上つて層別化するほど十分な資料がないのでここでは扱わない。70 $\mathrm{m}$ 以浅の各層

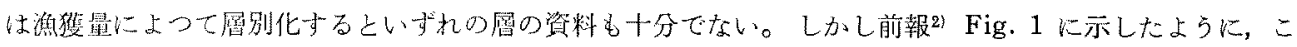

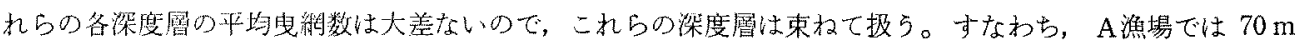
以浅・90 100 m 層・ $110 \mathrm{~m}$ 層の 3 つ層別化する。（以後便宜上，この上5にして層別化された各組を記

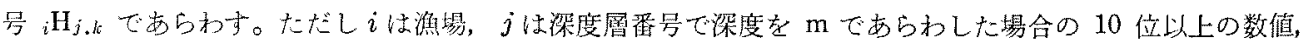

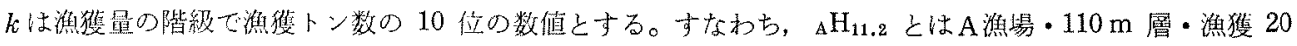

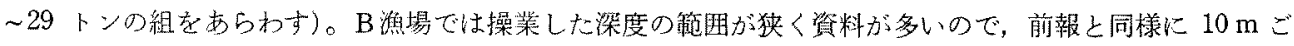
との 3 畨 $(100 \mathrm{~m} \cdot 110 \mathrm{~m} \cdot 120 \mathrm{~m})$ に分ける。C漁場では $110 \sim 130 \mathrm{~m}$ の各層の資料は少ないが他は十分市 るので, $110 \sim 130 \mathrm{~m} \cdot 140 \mathrm{~m} \cdot 150 \mathrm{~m}$ の3 層に分ける。しかし, ${ }_{A} \mathrm{H}_{7.4} \cdot{ }_{\mathrm{A}} \mathrm{H}_{11,1} \cdot{ }_{\mathrm{A}} \mathrm{H}_{11.2 .} \cdot{ }_{\mathrm{B}} \mathrm{H}_{12.1} \cdot{ }_{\mathrm{B}} \mathrm{H}_{12.2}$ ・ $\mathrm{CH}_{14.1} \cdot \mathrm{cH}_{14.2}$ の各組は資料㔔少ないのでここでは扱かない。

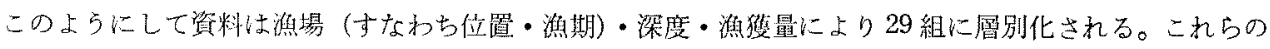
各組ごとに曳網回数の頻膺分布をしらべた。 


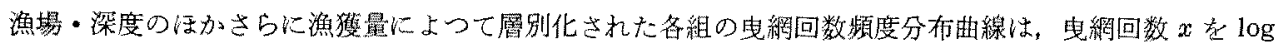

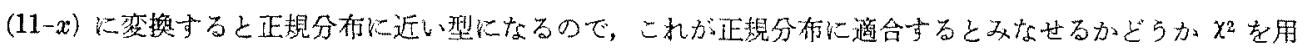

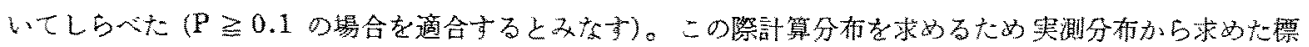

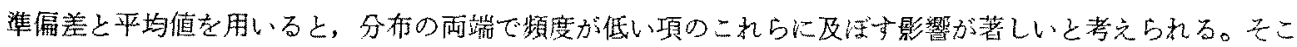

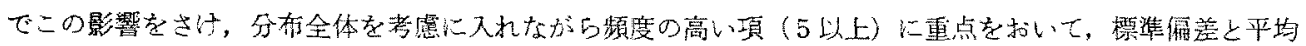

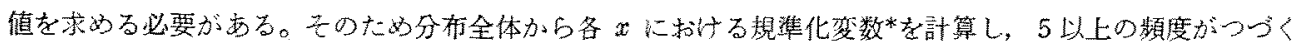

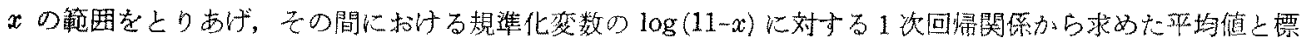

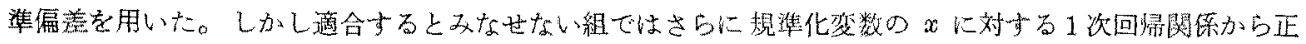

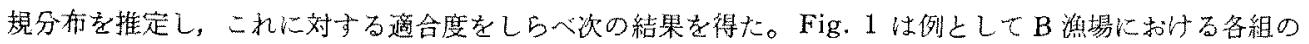
実测分布之計算分栝を示したものである。

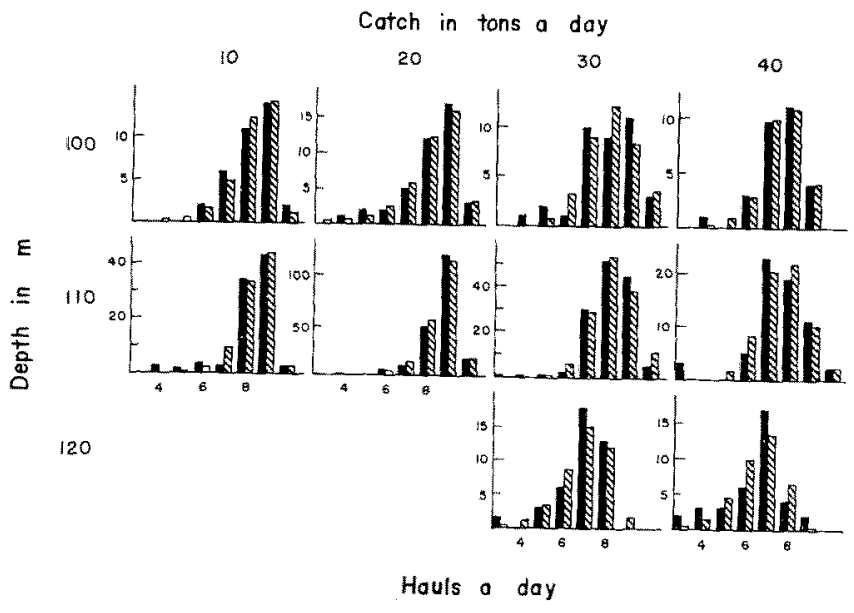

Fig. 1. Comparison of the observed and the estimated frequency distributions of day-and-boats with respect of daily hauls per boat (Area B).

Note: The filled histogram shows the observed series; whereas the hatched one, the estimated series. The ordinate is frequency in daymand-boats. The estimated series in three groups of samples-(100 $\mathrm{m}, 30$ tons), (110 $\mathrm{m}, 30$ tons), and (110 $\mathrm{m}, 40$ tons)-are based on the hypothesis that the frequency of day-and-boats plotted against the number of daily hauls a boat $(x)$ is agreeable to the normal series; but those in the groups of the rest are based on other hypothesis that the frequency plotted against $(11-x)$ on logarithmic scale is agreeable to the normal series.

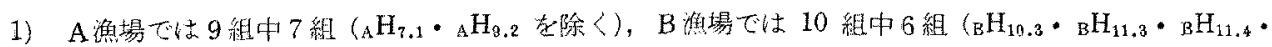

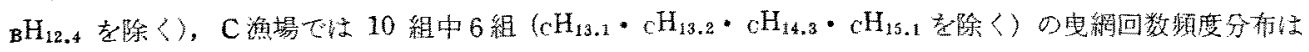

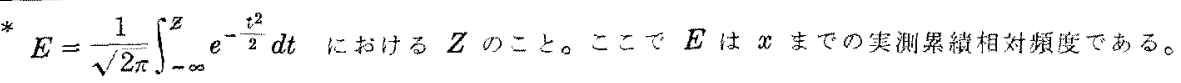


回数 $x$ を $\log (11-x)$ に变換すると正規型に適合する $(\mathrm{P} \geqq 0.1)$ 。

2) $\mathrm{A}$ 激場の 1 組 $\left(\mathrm{AH}_{7.1}\right)$ と B漁場の1組 $\left({ }_{\mathrm{B}} \mathrm{H}_{12.4}\right)$ はこの分布にかなり近似する $(0.1>\mathrm{P}>0.05) 。$

3）この分布に適合すると又なせない組の5ち， B 澳場の漁獲量が多い3 組 $\left(\mathrm{BH}_{10,3} \cdot{ }_{\mathrm{B}} \mathrm{H}_{11,3} \cdot{ }_{\mathrm{B}} \mathrm{H}_{11,4}\right)$ は 正規分布に適合する。 ${ }_{\mathrm{A}} \mathrm{H}_{9,4}$ は前者に適合するが，正規分布によりよく適合する。

4) $\mathrm{CH}_{13.1} \cdot \mathrm{CH}_{13.2}$ の両組では，或絧回数が 7 または 8 回に集中し，頻度 5 以上の階級が 3 以上とれない ので 观娭定を適用することができないが，前者に上く近湖するらしい。

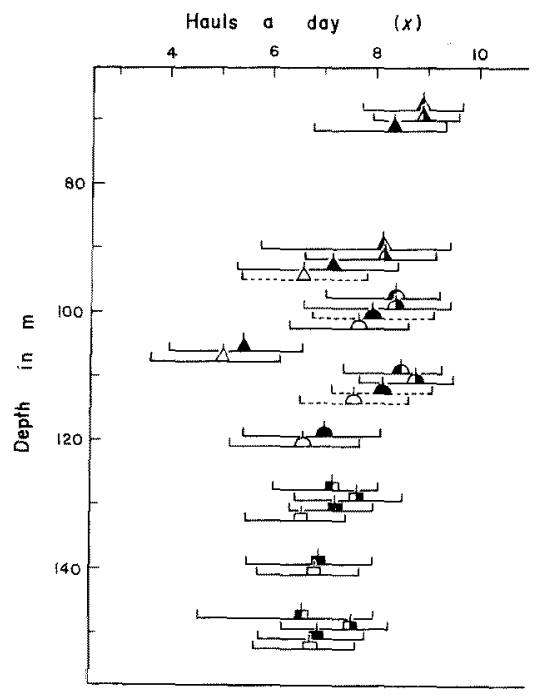

Fig. 2. Bathymetric change in the average of daily hauls a boat, with reference to that in the standard deviation (After stratification into the four grades of daily catch of 10 ton intervals).

Note: Triangle signifies the group observed in Area A; half circle, in Area B; and square, in Area C. The open mark symbolizes the group, the daily catch per boat of which is in the range of 40 to 49 tons; the filled one, 30 to 39 tons; the mark with right half filled, 20 to 29 tons; and that with left half filled, 10 to 19 tons. The true line shows the range of standard deviation of daily hauls per boat of the group of samples, the frequency of which plotted against (11-x) on logarithmic scale is agreeable to normal series; whereas the broken one shows that of the group agreeable to normal series (where a boat conducted $x$ hauls a day).
5) しかし ${ }_{A} \mathrm{H}_{9.2} \cdot{ }_{\mathrm{C}} \mathrm{H}_{14.3} \cdot{ }_{\mathrm{C}} \mathrm{H}_{15.1}$ の3 組はいずれの 計算分布にも適合するとみなせない。

次に，同じ階級の潐獲をあげた日に行なつた电絧回数 の深度変化と, 各深度層に拈いて潐獲舅の相異が戔網回 数に及ぼす影響を知るため，各組の平均电網回数と標準 编差を Fig. 2 に示した（いずれの分布にも適合すると みなせない組では $x$ のまま口り $\log (11-x)$ に变换す る方が突测分布に近つくので嫢準化变数の $\log (11-x)$ に対与る 1 次回棂関係から求めた值を示す)。この図か ら次の傾向が認められる。

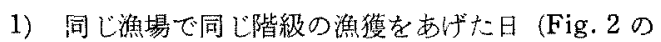
同一記号の組）に行なつた电網回数は, 深度の増加にし たがつて減少する。この㑯向はA漁場では特に顕著であ り，C漁場では極めて弱い。また同様な㑯向は漁獲量に よつて畨別化する前に乎群められた。

2)同じ深度層では，电絧回数は漁獲が多いはど娍少 する。ただし，各樑度層とも潐獲量が 10〜19トンの組 の平均曳網回数は 20〜29トンの組のそれと等しいか逆 にやや減少与る。

3) 戎網回数の標準痛差は，漁獲量に関係なく漁場之 樑度によつて異るらしい。しかし ${ }_{\mathrm{CH}_{15.1}}$ のそれは同じ 深度に括ける他の漁獲階級のそれより大きい。

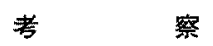

前報 ${ }^{2}$ では各船が 1 日に戋網した回数は深度が增加す るにしたがつて減少する傾问があることを報告した。し かし媣度と共に海獲量が増加するのでその影䇾を分離す るために，さらに激獲量によつて層別化して曳網回数の 深度变化をしらべ次のことがあかつた：漁場（すなわ ち位置・漁期) - 深度・漁獾县によつて層別化された 29 組中 19 組では，各船 1 日の曳絧回数 $x$ を $\log (11-x)$ に変換すると，頻度分布は正規分有によく適合し，他の 4 組はこれに近似する。残りの6 組中 3 組は曳網回数そ の乎のの分布が正規分布以適合するが，他の3 組はいず れの分布にも適合しない。

いずれの分布にす墑合しないこれらの3 組について原 記録をしらべ次のことがわかつた：1）潐獲が少なかつ 
a)

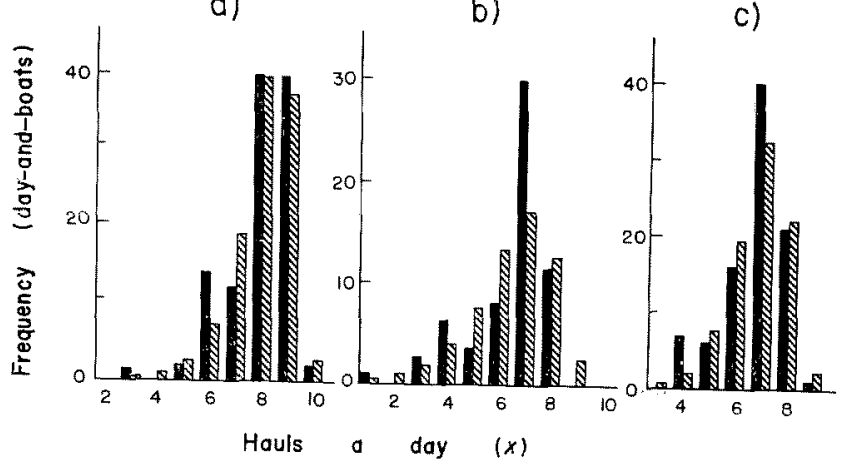

Fig. 3. Bimodality in the frequency distributions of daily hauls a boat found in the groups agreeable neither to $\log (11-x)$ normal nor to normal distribution.

Note: a) ${ }_{\mathrm{A}} \mathrm{H}_{9.2}$ (Area A, 85 to $104 \mathrm{~m}$ deep, yielded 20 to 29 tons per day per boat) b) $\mathrm{H}_{15.1}$ c) $\mathrm{CH}_{14.3}$

The filled histogram shows the observed series; whereas the hatched one is the estimated series based on the hypothesis that the frequency of day-and-boats plotted against $(11-x)$ on logarithmic scale is agreeable to the normal series.

た ${ }_{\mathrm{A}} \mathrm{H}_{9.2}$ と $\mathrm{CH}_{15.1}$ の2 組では，Fig. 3 に示すよらに1日8・9 または7回にみられるモードの他に6回 または 4 回比第 2 のモードらしい値がZられるためいずれの分布にも適合しない。このように操業回数が少 なくそのため澳獲が少ない例のらち $\mathrm{CH}_{15.1}$ に含まれるものは大部分 9 月下旬の藻獲が急減した終㴔直前に 集中しており， ${ }_{A} \mathrm{H}_{9.2}$ に含紊れるもの恃定の日に集中しないが，そのような例がみられる日でも他の大部

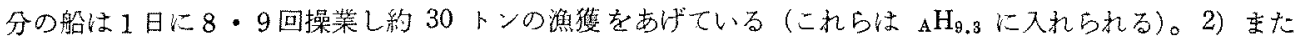
櫵獲が多かつた $\mathrm{CH}_{14.3}$ の組では，Fig. 3 に示すように 1 日4电網の頻度が高すぎるためいずれの計算分

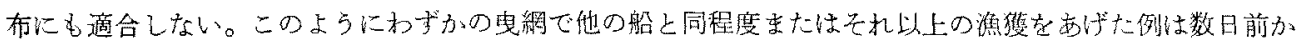
ら引続いて母船の処理能力を上回る㴔獲（1日に合計 650 ７00 トン以上）を奶げている日に数隻ずつの船 でみられ，この上らな船は特定の船でなく日によつて変わる。

このよらにこれらの各組では第2のモードに相当する例は1 日中普通に操業したとは考兊られないすな わらいずれの分布にす適合しないこれらの3 組も $\log (11-x)$ 正規型から变形したと考えられる。

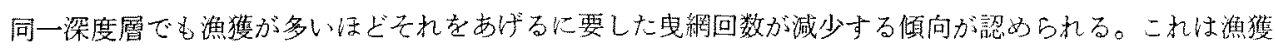
が多いほど1網の作業時間が長くなるためと考文られるが，この資料てはこれ以上険討できない。

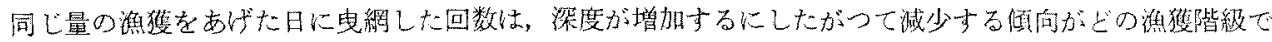
も認められる。したがつて漁獲量に上つて層別化する前比も認められたこの倾向は，深度に上つて㺘獲量が 異なるためでなく，电網回数に及ぼす深度の直接的な影響かあるいは深度とともに变化する漁獾量以外の要 因によるらしい。

また1日に电網した回数の標準偏差は同じ激場の同し深度層では㴧獲量に関係なく大体近い値をとる傾向 にあるが， $\mathrm{CH}_{45.1}$ のそれはこの層の他の湧灌階級のそれより大きい。これは曳網回数の实测分布が計算分 布に適合しないのと同じょうに分布型が双峰型になつていることによるらしい。しかし同様の理由て適合し

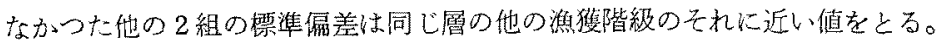

同一深度居で同じ量の漁獲をあげた場合です，平均曳絧回数が漁場によつて著しく異なる。これについて 主な対象になる魚種やその分布様式が潐場によつて異ることの影響を無視できないだろう。しかし漁場に上 


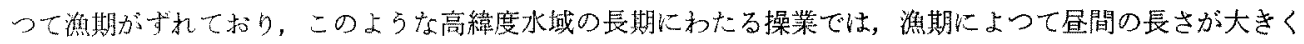
変化するにもかかわらず各船とも夜間は注とんど操栄しないので, 曳網回数の漁場による相異は各漁期にお。 ける昼間の長さと関倸があるかどらかについて検討する必要がある。そのほか, 漁期のはじめは操業に不慣 れであること，乗組員の心理状態が源期の進むにつれているいる変化することの影響なども無視できないた ろう。

要約

1. 前報2) ではベーリング海東部において 1963 年に出㴡したフィッシュミール船団に所属する各以東底 曳船が 1 日に电網した回数は，深陵とともに減少する傾向があることを報告した。しかし深度とともに海獾 量が增加するのでその影響を分離するために，さらに潐獲量によつて層別化し，1日1隻の史網回数と深 度および湶䌘量との関倸についてしらべた結果を報告する。

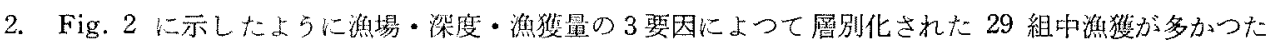
3 組の史網回数頻度分布は正規化されるが，19組のそれは 1 日 1 隻の史絧回数 $x$ を $\log (11-x)$ に变換す ると正規分布に適台し（ただしこのうちの1組は前者に上りよく適合する），他の4組はこれに近似し，残 りの3組もこの型から変形したと考えられる。きた海獲量によつて層別化する前はすべての組がこの型に適 合した。

3. 同じ攧場で同じ階級の源獲をあげた日の曳網回数 (Fig. 2 の同一記号の組) は, 深度の增加にした がつて減少する。この傎向はA源場では特に顕著であり, C 海場では極めて弱い。

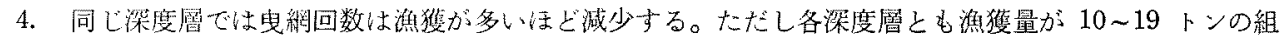
の平均曳新回数は 20〜29トンの組のそれに等しいか逆にやや減少する。

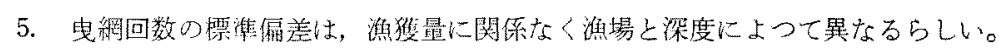

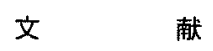

1) MaÉda, H. and S. Minami: This Bull., 31, 340 (1965).

2) Minami, S. and H. MAÉda: ibid., 31, 346 (1965). 